\title{
WHEN THE PUBLIC AGENDA CLASHES
}

\author{
WITH RESEARCH \\ Thomas H. Rosenquist \\ Director of Research Development \\ University of Nebraska Medical Center
}

In November of 1999, the Omaha World-Herald ran a page one article, an exposé as it were, about a research project at the University of Nebraska Medical Center (UNMC) that utilized embryonic neurons obtained from elective abortions, at a clinic in the suburban Omaha town of Bellevue. This work was sponsored by a research grant from the National Institutes of Health, and had been ongoing for about two years at the time the article was published. The use of these cells had been considered by a subcommittee of the UNMC Institutional Review Board for the protection of research subjects, although the tissue is considered to be exempt, and the review was elective; and the grant had been accepted by the University of Nebraska Board of Regents, as required by law. The use of these cells for research purposes was legal by the laws of the United States of America, and the State of Nebraska. The research was addressing a major, dreaded, incurable neurodegenerative disorder. Nevertheless, the publication of the article caused a sensation that preoccupied and disrupted the administrations of both the medical center and the university system as a whole, for several months. Several important lessons were learned by UNMC from this experience. Three of the most important lessons for other institutions are outlined below.

Lesson 1: Some research issues are explosive, divisive and dangerous.

The article about UNMC fetal cell research resulted in an immediate polarization of the people and organizations of the state. Polls reported that the people of the state were profoundly divided among supporters and opponents of the work. The University of Nebraska Board of Regents voted unanimously to support UNMC, while members of the Nebraska unicameral legislature, the majority of whom declared their opposition, began to discuss the development of a law to ban the work. A bill introduced to the Nebraska legislature that would have banned fetal cell research was withdrawn in March of 2000 because of a skillful filibuster by an Omaha legislator who supported the bill. However, it is highly likely that the legislature will activate the debate in the next legislative session. 
The Omaha World-Herald published scores of letters condemning the work, as well as fewer letters supporting the work; the World-Herald also published a series of editorials that urged the legislature to keep "hands off" this and other research activities of the University. The governor of Nebraska announced his unequivocal opposition to the research, while the president of the University system was as unequivocally supportive. The de facto debate between these two leaders was publicized widely; their pictures and a description of the debate were carried in Science and other national publications.

When it became associated with this issue, UNMC entered the abortion war, where, we were to find, there is no compromise and no holds are barred. Anti-abortion and right-to-life groups entered the fray with a passion. The university has learned that these groups include members to whom this issue is nothing less than total war, wherein all's fair, including lying, disinformation, and harassment. It is well-known that these tactics have extended to assault or even murder in some cases, although not yet in the present case. Others in the anti-abortion movement may be more law-abiding, but are no less passionate on the issue. Their tactics against the university have included lawsuits, requests for federal audits of research activities, and political activism in support of regents and legislators who oppose the research.

Responses similar to those experienced by UNMC for fetal cell research also may be anticipated for other controversial research issues, including the use of mammals in research, and the creation of transgenic animals or plants.

Lesson 2: A university or medical center that decides to conduct controversial research needs to be fully prepared.

There are several levels of preparation that need to be addressed. First, the university needs to recognize and fully understand the degree to which some research may trigger a negative response among a vocal, passionate, and possibly violent segment of the population. Some opponents may be positioned to impact negatively upon the resources of the university. For example, citing the UNMC experience, the governor and key legislators; potential donors also could have been perturbed. The UNMC experience has not yet shown a way to permit the faculty to pursue legitimate but sensitive research, while mollifying the opponents of the research. Indeed, it may not be possible for a university to do so. However, it will be critical for the university entering this interesting arena, to understand the potential results.

Second, all regulatory issues pertaining to the sensitive research need to be considered scrupulously, and addressed completely. If the 
typical research project is reviewed twice, issues such as human fetal cell research and genetically engineered animals or plants need to be reviewed six times.

Third, the university and the investigators need to be prepared well in advance to respond to the public release of the story. Immediately upon the release of the story, the university needs to be able to provide a strong, cogent, convincing and completely documented response that includes all of the following: the high value of the work to the people of the state; the degree to which the work is legal, ethical and moral; a list of other universities around the country who do similar work; and a detailed history of approval for the work at the university, state and national levels. If possible, the university should be prepared to show that it is aware of the sensitivity of the issue, and has been exploring alternative ways to obtain the same key research results.

Lesson 3: A university must be aggressive in assuring the integrity, independence, and objectivity of its research enterprise.

A university must assure that her researchers are able to pursue their legitimate research in an environment of academic freedom, without the imposition of political, religious or other biases. Most important, the university must work to assure the safety of the faculty and their families. 